\title{
Employment opportunities and skills necessary for entry-level employment in the timber industry
}

\author{
Robert E. Driscole \\ West Virginia University
}

Follow this and additional works at: https://researchrepository.wvu.edu/etd

\section{Recommended Citation}

Driscole, Robert E., "Employment opportunities and skills necessary for entry-level employment in the timber industry" (2004). Graduate Theses, Dissertations, and Problem Reports. 1961.

https://researchrepository.wvu.edu/etd/1961

This Thesis is protected by copyright and/or related rights. It has been brought to you by the The Research Repository @ WVU with permission from the rights-holder(s). You are free to use this Thesis in any way that is permitted by the copyright and related rights legislation that applies to your use. For other uses you must obtain permission from the rights-holder(s) directly, unless additional rights are indicated by a Creative Commons license in the record and/ or on the work itself. This Thesis has been accepted for inclusion in WVU Graduate Theses, Dissertations, and Problem Reports collection by an authorized administrator of The Research Repository @ WVU. For more information, please contact researchrepository@mail.wvu.edu. 


\title{
Employment Opportunities and Skills Necessary \\ for Entry-Level Employment \\ in the Timber Industry
}

Robert E. Driscole, CF

Thesis submitted to the

Davis College of Agriculture, Forestry

and Consumer Sciences

\author{
In partial fulfillment of the requirements \\ for the degree of \\ Master of Science \\ in \\ Agricultural and Environmental Education
}

Approved by

Stacy A. Gartin, Ph.D.

Harry N. Boone, Jr., Ph.D.

Deborah A. Boone, Ph.D.

Division of Resource Management

Morgantown, WV

2004

Keywords: Timber Industry, Employment, Skill Requirements, Logger Training 


\begin{abstract}
Employment Opportunities and Skills Necessary for Entry-Level Employment in the Timber Industry
\end{abstract}

\title{
Robert E. Driscole, CF
}

The purpose of this study was to determine the skills and knowledge needed by entrylevel employees in the timber harvesting industry as viewed by the Owner/Operators in the four county area of northern West Virginia. The population consisted of 163 owner/operators in Monongalia, Marion, Taylor and Preston counties. A descriptive survey approach was utilized to explore the training need for persons wishing to enter the timber harvesting industry. The most significant finding was that the owner/operators viewed good work ethics as the most important trait for entry-level employees in the timber industry. 


\section{DEDICATION}

Dedicated to my family. To my wife, Joan, thank you for all that you do, your friendship and your love. Thirty years does not seem like such a long time. To my sons, sometimes I'm not sure if I'm raising the bar or just struggling to keep up. Keep up the pressure. 


\section{ACKNOWLEDGEMENTS}

To Deborah and Harry Boone, I wish to express my deep appreciation for your help on the project. Your attention to detail and your expertise have helped to make this possible.

To Kerry Odell your teaching style made learning enjoyable. Your door was always open and you always took the time to talk. Thank you for all you have done and your friendship.

To Stacy Gartin, thank you does not seem like enough. You've helped keep me on track with your easy-going nature, never pushing just quietly suggesting. Your friendship over the years and during all those soccer games has been gratefully accepted. 


\section{TABLE OF CONTENTS}

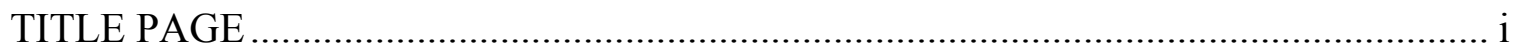

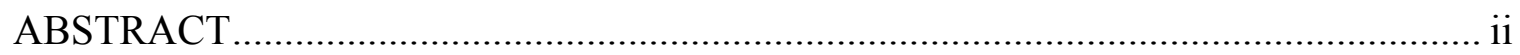

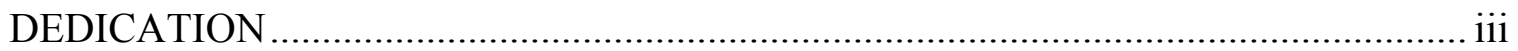

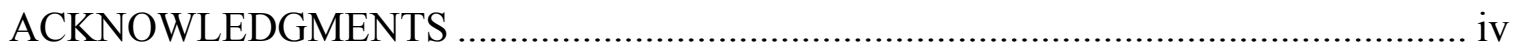

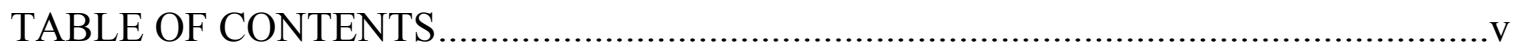

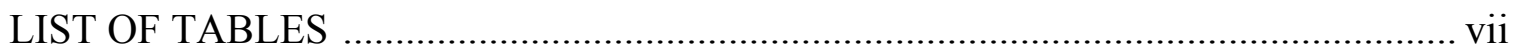

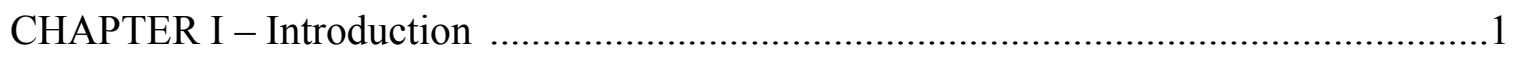

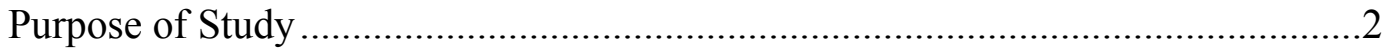

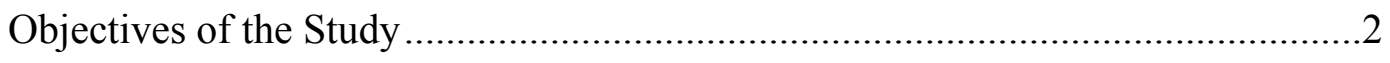

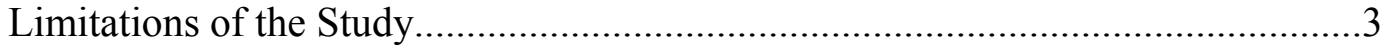

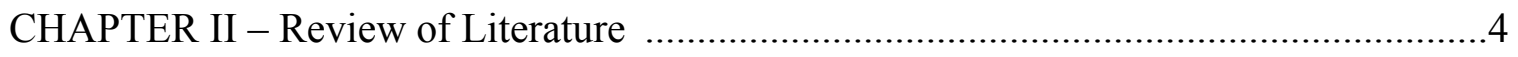

CHAPTER III - Design and Methodology ............................................................

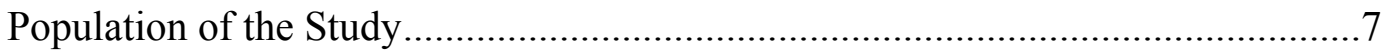

Objectives of the Study ..........................................................................

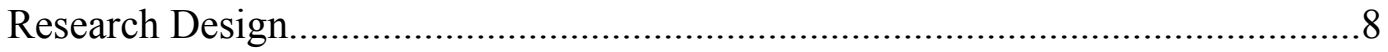

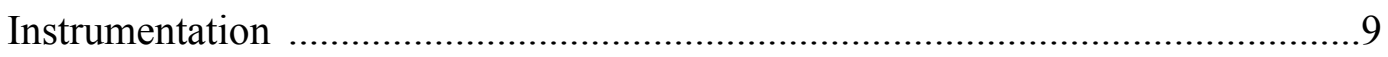

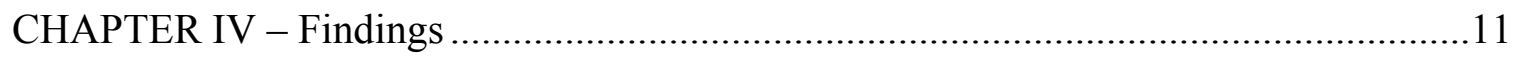

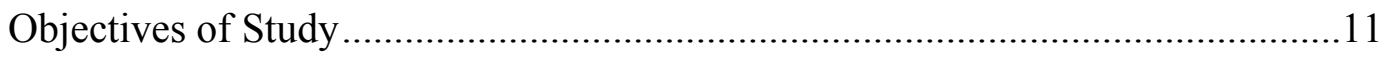

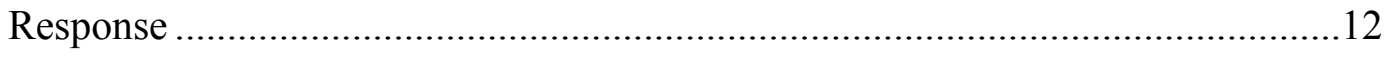

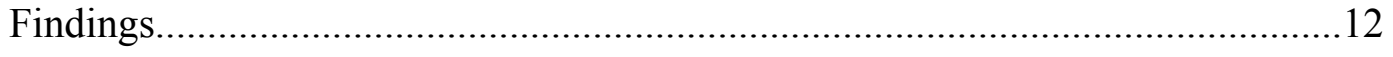

CHAPTER V - Summary, Discussion and Recommendations ...................................17

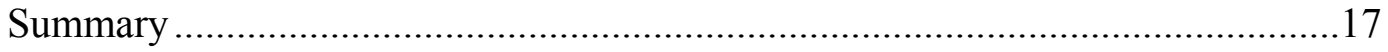




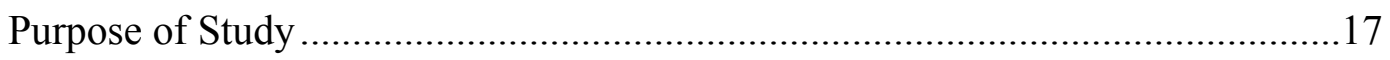

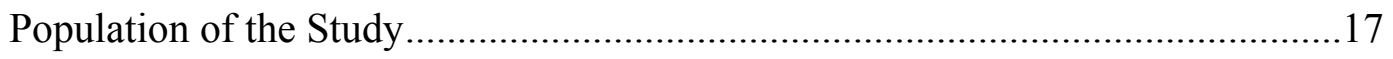

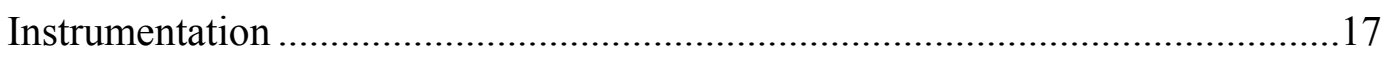

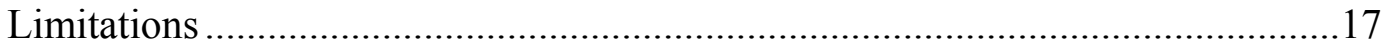

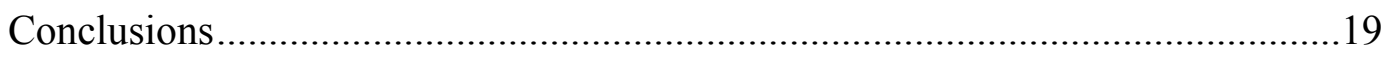

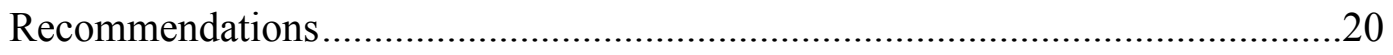

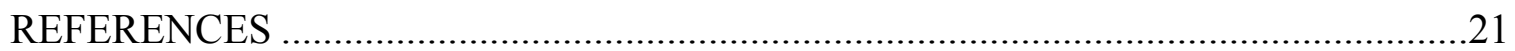

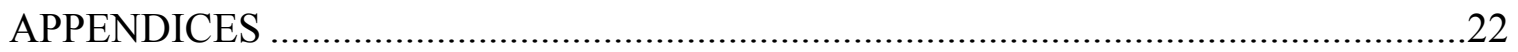

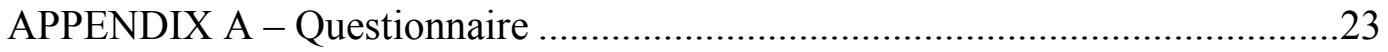

APPENDIX B - Initial Cover Letter ..........................................................26

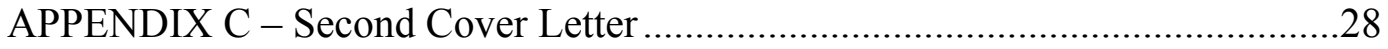

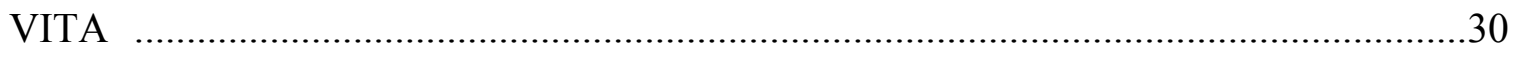




\section{LIST OF TABLES}

TABLE

1. Results of Questionnaire: Areas of Safety Needs ................................................5

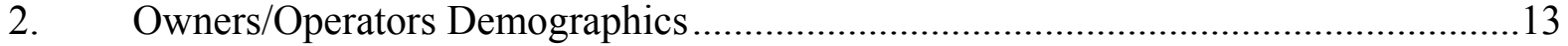

3. Owners/Operators Who Were Certified Loggers ................................................13

4. $\quad$ Number of Trained Workers Hired Annually ...................................................... 14

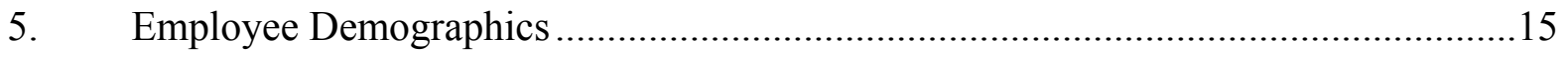

6. Basic Skills and Knowledge Needed as Viewed by Owners/Operators .....................16 


\section{CHAPTER I}

Introduction

The need for properly trained persons entering the timber harvesting industry is increasing. The total number of timber operators at the end of 1995 was 1487, of these 154 were new in 1995 . This represents a $10 \%$ increase. The number of certified loggers also increased in 1995 by 146 to a total of 1721 for an $8.5 \%$ increase. In addition, 99 temporary certifications were issued and had not yet been made permanent. Between the years 1993-1995 there was an increase of $30 \%$ in the number of certified loggers in West Virginia (Whipkey, WV Division of Forestry, personal communication, February 21, 1996).

On March 1, 1995 during a general question and answer session at a workshop for Occupational Safety and Health Administration compliance for loggers, when asked by one of the Appalachian Hardwood Center, Division of Forestry, West Virginia University staff "what was needed in terms of training" one of the timber operators made the comment that employees entering the timber harvesting industry lack the skills necessary to perform entry level jobs in a safe and efficient manner.

Some of the major skills needed to compete for timber-harvesting jobs in today's job market are; first-aid training, chainsaw safety and maintenance, best management practices (BMPs), proper felling technique and operation and maintenance of logging equipment. A knowledge of log grades and scaling would give entry level employees a better understanding of how the logs produced relate to lumber grades at the sawmill. Road layout and construction would be very helpful in harvesting operations. Training in the different silvicultural methods would give an understanding as to why foresters use these methods and how they benefit the forest. 
Proper training might best be given to potential workers while they are in the secondary school system, prior to employment. With the rising number of state and federal regulations, the rising cost of workers' compensation and the rising concern of timber harvesting by people outside the industry, there appears to be a need for well-trained workers.

Purpose of the Study

The purpose of this study was to determine employment opportunities and skills necessary for entry level employment in the timber harvesting industry as perceived by the owners/operators in the four county study area and to supply this information to the Morgantown Area Technical Center to assist in their decision whether or not to start a program in timber harvesting.

\section{Objectives of the study}

It was the intent of this study to determine what skills and knowledge are necessary, as perceived by the owners/operators in Monongalia, Marion, Preston and Taylor counties. Specific objectives of this study are as follows:

1. To identify the number and type of employees in the timber harvesting industry.

2. To determine employment opportunities and the needs of the timber harvesting industry in the West Virginia counties of Monongalia, Marion, Preston and Taylor.

3. To determine the importance of knowledge and skills necessary for logger certification.

4. To determine the importance of general forestry knowledge of employees in the timber harvesting industry.

5. To determine the importance of basic harvesting equipment skills possessed by entrylevel employees. 
6. To determine the importance of general education knowledge and skills.

7. To determine the importance of work ethics of entry level employees.

8. To determine demographic information of the owners/operators in the four county areas.

9. To determine the importance of training as perceived by the owners/operators in the four county areas

\section{Limitation of the Study}

This study is limited to the owners/operators in the timber harvesting industry in the four county (Monongalia, Marion, Preston and Taylor) study area in West Virginia. 


\section{CHAPTER II}

\section{Review of Literature}

There has always been a need for well-trained workers, regardless of the industry. In forestry, increased mechanization, the rapid pace at which harvesting occurs, and the environmental concerns which are dramatically affecting the industry, emphasizes the need for better trained workers to ensure the success of the industry.

Parade Magazine 1989 ranked timber-cutters and loggers as number one in order of risk with 129 deaths/100k. Ranking second was asbestos and insulation workers with 78.7 deaths/100k. Miners ranked $11^{\text {th }}$ with 37.5 deaths/100k and sawyers ranked $28^{\text {th }}$ with 15.4 deaths $/ 100 \mathrm{k}$.

For years the sawmilling and pulpwood cutting industries have been working under the regulations of Occupational Safety and Health Administration (OSHA). By definition, timber cutters did not fall under these regulations. In 1990, the West Virginia Forestry Association (WVFA) was asked to review and make recommendations to OSHA regarding regulations for timber harvesting. These regulations were due to take effect in the 1992.

The need for training has been recognized by the WVFA and the West Virginia Division of Forestry. With the adoption of logging regulations in 1992, a person desiring to become a certified logger is required to attend classes in standard first aid, best management practices (BMPs), and chain saw safety.

In 1992 a questionnaire was developed and distributed to all forest industries in West Virginia by Murriner and Pahl (Pahl, Appalachian Hardwood Center, Division of Forestry, West Virginia University, personal communication, March 20, 1996) to determine the training needs. In the area of safety, ten areas were identified. First Aid (see Table 1) was considered to be the 
most important area of training needed by those answering the 1992 questionnaire. Other areas of medium importance were chain saw safety, safe felling techniques, personal protection equipment, skidding safety, log truck safety, sawmill safety, back injury protection and respiratory hazards. Table 1 lists those areas, along with the number of people needing training and the ranking of importance, as reported by Murriner and Pahl at the WVFA safety committee meeting in May of 1993.

Table 1

Results of Questionnaire: Areas of Safety Training Needs

\begin{tabular}{lcc}
\hline & $\begin{array}{c}\text { \# Workers } \\
\text { needing training }\end{array}$ & Importance * \\
\hline First Aid & 438 & 2.84 \\
Chain Saw Safety & 172 & 2.45 \\
Safe Felling Techniques & 80 & 2.30 \\
Personal Protection Equipment & 269 & 2.29 \\
Skidding Safety & 51 & 2.18 \\
Log Truck Safety & 68 & 2.25 \\
Sawmill Safety & 171 & 2.72 \\
Fork Truck Safety & 145 & 2.26 \\
Back Injury Protection & 649 & 2.40 \\
Respiratory Hazards & 254 & 2.10 \\
\hline
\end{tabular}

* Ranking priority: 2.5 to 3 high: 1.5 to 2.49 medium: 1 to 1.49 low

Mercer County, West Virginia Technical Education Center had developed a wood production technology program for the hardwood lumber industry. Some of the more important topics are introduction to forestry equipment, first aid, computer application, operation of rough 
mill equipment, kiln operation, wood preservation and pressure treating.

A few states have developed logging safety handbooks to help loggers develop safe work habits. "The Vermont Logging Safety Handbook" produced by the University of Vermont Extension system is one example. North Carolina Forestry Association, Inc. has also developed a "Logger Safety Checklist Booklet"; each booklet was designed to be used for a year. This booklet would be kept with each logging crew or in the shop and each part of the booklet is filled out as training occurs, so there is a record of type and date of training. 


\section{CHAPTER III \\ Design and Methodology}

\section{Population of the Study}

The population for this study consisted of 163 owner operators in the timber harvesting industry in Monongalia, Marion, Preston and Taylor counties in West Virginia. These owner/operators were identified from a list of loggers supplied by the Appalachian Hardwood Center, Division of Forestry, West Virginia University.

\section{Objectives of Study}

What were the employment opportunities and skills necessary for entry-level employment in the timber harvesting industry and how do the following relationships affect perception of each:

1. To identify the number and type of employees in the timber harvesting industry.

2. To determine employment opportunities and needs of the timber harvesting industry in Monongalia, Marion, Preston and Taylor counties.

3. To determine the knowledge and skills necessary for logger certification or determine if logger certification was necessary.

4. To determine the importance of general forestry knowledge of employees in the timber harvesting industry.

5. To determine the importance of basic harvesting equipment skills possessed by entrylevel employees.

6. To determine the importance of general education knowledge and skills.

7. To determine the importance of work ethics of entry level employees.

8. To determine demographic information of the owners/operators in the four-county 
areas.

9. To determine the importance of training as perceived by the owners/operators in the four county study areas.

\section{Research Design}

A descriptive survey approach was utilized to explore the training needs for persons wishing to enter the timber harvesting industry. The instrument was designed to determine the skills and knowledge needed for an entry-level employee as perceived by owners/operators within the study area. The advantage of description research is that it allows the researcher to collect a wide scope of information from a large population; it deals with real situations; can measure what actually exists and data can be collected by mail or in personal interviews or by the telephone. The disadvantages are the demands on time and money; sampling error, nonresponse error, selection error can jeopardize external validity; frequently difficult to obtain valid data; the interpretation possible is description only, and explanation or prediction of phenomena is not possible as research is designed to describe only (Ary, Jacobs, and Razavieh, 1990).

There are five types of error that exist in descriptive research which need to be controlled. The study was premeditated to restrict possible error due to the following:

Frame error: A complete frame of the population was compiled by using the list of Timber Operators provided by the West Virginia State Bureau of Commerce, Division of Forestry; therefore, frame error could be controlled.

Sampling error: The entire population of the four-county study area was included in this study; therefore, no sampling error occurred in this study.

Measurement error: The procedure for testing validity and reliability will be discussed in the instrumentation section. 
Selection error: The entire populations of owners/operators were surveyed. This prevented selection error.

Non-response error: Non-respondents were not measured in this study.

\section{Instrumentation}

The instrument was designed to determine the skills and knowledge needed for an entrylevel employee as perceived by owners/operators within the study area. A survey packet was sent to all (163) owners/operators in the study population. Included in the packet was a letter explaining the purpose and importance of the survey along with the two-page survey instrument. Following the initial mailing, a second packet including another survey was sent to those not responding to the first, again explaining the importance of their response.

The two-page questionnaire in this study consisted of several parts. The first part asked questions related to the number of employees working in different aspects of the operation, harvesting, transportation, and maintenance. This section also asks how many people were employed in the operation, how many were certified loggers, and approximately how many new employee were hired each year. In addition, the owners were asked if they would be willing to hire entry-level workers who had been trained in a forestry program at the secondary school level and what would be the average starting salary they would pay a person with this type of training. The frequencies at which new employees were hired in each of the four areas of felling, skidding, transportation, and maintenance were considered important information for this study.

The next section addressed the requirements necessary for loggers to be certified as regulated by the West Virginia State, Division of Forestry. It was determined important to see how the owners viewed these requirements. Was there a relationship between their years of experience, age, number of employees and county? 
The next group of questions addressed the importance of general forestry knowledge; timber cruising, log grading, road layout and construction, silviculture, and surveying. This information was important for more experienced loggers, but how important was it for an entrylevel employee?

The next series of questions addressed what skills would be needed to enter the timber industry as an equipment operator, such as skidder, dozer, log loader, sawbuck, feller-buncher, as well as the importance of maintenance of this equipment. They were also asked the need for commercial drivers license (CDL).

In addition to the skills and knowledge related to forestry, timber operators were asked about basic life skills such as business math, writing, and oral communications. The last two groups of questions deal with the expectations of the employer, such as attendance and punctuality, cooperation with co-workers, and the amount of supervision needed. The last few questions collected demographic information on the timber operator and was used to determine differences in options based on age, years of experience, and whether the operator was a certified logger. 


\section{CAHPTER IV}

\section{Findings}

The purpose of this study was to determine employment opportunities and skills necessary for entry level employment in the timber harvesting industry as perceived by the owners/operators in the four county study area and to supply this information to Morgantown Area Technical Center to assist in their decision whether or not to start a program in timber harvesting. A descriptive survey approach was utilized to explore the training needs for persons wishing to enter the timber harvesting industry.

\section{Objectives of the Study}

It is the intent of this study to determine what skills and knowledge are necessary, as perceived by the owners/operators in Monongalia, Marion, Preston, and Taylor counties. Specific objectives of this study are as follows:

1. To identify the number and type of employees in the timber harvesting industry.

2. To determine employment opportunities and needs of the timber harvesting industry in Monongalia, Marion, Preston, and Taylor counties.

3. To determine the importance of knowledge and skills necessary for logger certification.

4. To determine the importance of general forestry knowledge of employees in the timber harvesting industry.

5. To determine the importance of basic harvesting equipment skills possessed by entrylevel employees.

6. To determine the importance of general education knowledge and skills.

7. To determine the importance of work ethics of entry level employees. 
8. To determine demographic information of the owners/operators in the four county areas.

9. To determine the importance of this training as perceived by the owners/operators in the four-county areas.

In addition to the above objectives, demographic data was collected related to:

1. Was the owners/operators a certified logger?

2. Age of the owners/operators.

3. Years of experience.

4. Number of employees.

\section{Response}

The population of 163 individual owners/operators within the four county study area of Monongalia, Marion, Preston, and Taylor in West Virginia were mailed a survey questionnaire (Appendix A). On May 4, 1995, a cover letter (Appendix B) asking for their assistance in completing this study, the questionnaire, and a self-addressed stamped envelope were mailed to the target population. A follow up letter (Appendix C) was then sent on July 6, 1995, urging those who had not completed and returned the questionnaire to do so. The study had a response rate of $23.93 \%$ with 39 out the 163 survey population responding.

\section{Findings}

The population included 39 owners/operators of timber harvesting businesses.

Demographics on age and years of experience of these owners/operators are shown in Table 2. Twenty-nine respondents reported their age. Ages ranged from 31 to 75 with an average of 45 . Years of experience ranged from a minimum of two to a maximum of 60 in the business, with an average of 21.2 years in the timber harvesting business. 
Table 2

Owner/Operator Demographics

\begin{tabular}{lccccc}
\hline & & & & & \\
& N & Minimum & Maximum & M & SD \\
\hline Age & 29 & 31 & 75 & 45.76 & 11.50 \\
Years Experience & 30 & 2 & 60 & 21.20 & 14.35 \\
\hline
\end{tabular}

Twenty-six out of 28 owners/operators reported that they are certified loggers. Table 3 shows that $92.90 \%$ of the responders were certified loggers.

Table 3

Owners/Operators who where certified loggers

\begin{tabular}{lcccc}
\hline & & & $\%$ \\
& $\mathrm{~N}$ & Yes & No & Certified \\
\hline Certified & 28 & 26 & 2 & 92.90 \\
\hline
\end{tabular}

Twenty-two (56.4\%) of the owners/operators reported hiring at least one and no more than two trained workers in their operation (see Table 4). Seventeen owners/operators indicated that they did not hire additional labor. 
Table 4

Number of Trained Workers Hired Annually

\begin{tabular}{lccccc} 
& N & Minimum & Maximum & M & SD \\
\hline & & & & & \\
Hired Trained Workers & 22 & 1 & 2 & 1.05 & 0.21 \\
\hline
\end{tabular}

The maximum number of employees used by one owners/operators was 42 employees (see Table 5). The average number of employees was six. The number represents employees that perform different duties within the harvesting operation, such as certified logger, harvesting, transportation and maintenance. Seven owners/operators $(17.95 \%)$ reported having at least one certified logger employee. One reported having six employees as certified loggers. The average number of persons employed in the actual harvesting operation was three, with two reporting as many as nine employees. Six owners/operators $(15.4 \%)$ had only one employee. Thirty-three percent of the owners/operators reported that there was only one person employed in the transportation of logs, with one owner/operator reporting six individuals employed to transport logs. Twenty-eight (71.79\%) of the 39 respondents reported as having an average of two persons assigned to maintenance. Two respondents reported having no one assigned to maintenance and ten owners/operators reported having two employees assigned to maintenance.

Seventeen $(43.59 \%)$ respondents answered the question related to new employees being used to drive skidders. Five owners/operators reported hiring one new skidder operator and one reported hiring two skidder operators. Thirty-three percent $(n=20)$ of the respondents answered that they did not hire any new employee for maintenance. Six owners/operators reported that 
they hired at least one and one owners/operators reported hiring two new employees for maintenance. On the average two new employees where hired for each of these areas.

The last question in this series of questions about employees was related to salaries. Sixty-one and a half percent (61.5\%) of the owners/operators responded to the question. The average salary paid for employees in the timber harvesting business was $\$ 5.76$, per hour with a minimum of $\$ 4.00$ and the maximum of $\$ 8.00$.

Table 5

Employee Demographics

\begin{tabular}{lccccc}
\hline & N & Minimum & Maximum & M & SD \\
\hline Employees & 31 & 0 & 42 & 6.35 & 8.15 \\
Employees-Certified Logger & 28 & 0 & 6 & 2.00 & 1.39 \\
Employees-Harvesting & 27 & 0 & 9 & 3.30 & 2.57 \\
Employees-Transportation & 28 & 0 & 6 & 1.68 & 1.49 \\
Employees-Maintenance & 28 & 0 & 6 & 2.32 & 1.72 \\
New Employees-Skidding & 17 & 0 & 2 & 0.41 & 0.62 \\
New Employees-Maintenance & 20 & 0 & 2 & 0.40 & 0.60 \\
New Employees-Felling & 22 & 0 & 2 & 0.50 & 0.67 \\
New Employees-Transportation & 22 & 0 & 2 & 0.59 & 0.59 \\
Starting Salary & 24 & $\$ 4.25$ & $\$ 8.00$ & $\$ 5.76$ & 1.02 \\
\hline
\end{tabular}

On the question of new employees 22 of the owners/operators reported that they hired two new employees. They also reported hiring two new employees for transportation of loge. Table 6 documents the way in which the owners/operators view the general knowledge 
skills such as work ethics, knowledge of forestry, basic harvesting skills, logger certification and basic education skills. Some of the general knowledge skill data was related to attendance, minimal supervision, reading and writing skills, equipment operation, timber cruising, etc. (see Appendix A). Participants in this survey were asked to rank these skills from 4 (very important) to 1 (not important).

Table 6

Basic Skill Knowledge Needed as Viewed by Owner/operators

\begin{tabular}{lccccc}
\hline & N & Minimum & Maximum & M & SD \\
\hline Work Ethics & 27 & 2.5 & 4 & 3.54 & 0.41 \\
Logger Certification & 27 & 1.75 & 4 & 3.42 & 0.66 \\
Basic Harvesting Skills & 26 & 1.83 & 4 & 3.27 & 0.70 \\
General Education Skills & 27 & 1.25 & 4 & 3.06 & 0.56 \\
Forestry Knowledge & 24 & 1 & 4 & 2.74 & 0.85 \\
\hline
\end{tabular}

Ranking priority: 4very important to 1 not important

Owners/operators surveyed considered good work ethics to be very important (3.54). This was closely followed by logger certification (3.42). General education skills (3.06), although important according to owners/operators, it was not as important as basic harvesting skills (3.27). Of least importance was the area of forestry knowledge (2.74), such as timber cruising, surveying, silviculture, etc. 


\section{CHAPTER V}

Summary, Conclusion and Recommendation

\section{Summary}

Purpose of the Study

To determine employment opportunities and skills necessary for entry level employment in the timber harvesting industry as perceived by the owners and operators in the four county study area and to supply this information to Morgantown Area Technical Center to assist in their decision whether or not to start a program in timber harvesting.

\section{Population of the Study}

The population for this study consisted of 163 owners/operators in the timber harvesting industry in the four county study areas of Monongalia, Marion, Preston and Taylor. These owners/operators were identified from a list of loggers supplied by the Appalachian Hardwood Center, Division of Forestry, West Virginia University. Thirty-nine of the target population responded for a $23.9 \%$ response rate.

\section{Instrumentation}

A descriptive survey approach was taken to explore the training needs for persons wishing to enter the timber harvesting industry. The survey instrument was designed to determine the skills and knowledge needed for an entry-level employee as perceived by owners/operators within the study area.

\section{Limitations of the Study}

This study was limited to the owners/operators in the timber harvesting industry in the four county (Monongalia, Marion, Preston and Taylor) study area in West Virginia. 
An important finding in this study was the fact that over two-thirds (27 of the 39 responders) of the owners/operators noted that good work ethics were the most important attribute, which should be possessed by an employee. Good work ethics was related to good attendance, punctuality, cooperation with co-workers, and the ability to work with minimal supervision. This would imply that owners/operators in the timber harvesting industry are looking for entry-level employees who learn quickly, report on time for work, take initiative in completing tasks, possess a positive attitude, and are congenial.

Following closely behind good work ethics were the skills needed to be a certified logger. Knowledge of BMPs (Best Management Practices), first aid and CPR, basic chain saw safety and advanced chain saw techniques were important. These skills generally required additional training off site, and the individual employee that possesses a good work ethic is most likely to be selected for training as a certified logger.

With a ranking of medium importance, basic harvesting skills, such as equipment operation, buck saw operation, and maintenance of equipment, were all skills that were closely related to those needed for being a certified logger. However an entry-level employee must show some level of proficiency with these skills in order to be employed in the timber industry. Basic education skills, reading, writing, math and oral communication were raked of somewhat lesser importance. These received a raking of 3.06 on the scale 4-very important to 1not important.

Of much lesser importance were the skills relating to general forestry skills such as timber cruising, silviculture, log grading, surveying and road layout, and construction. These would be skills and duties performed by professionally trained foresters hired by the owners/operators of a timber business. With a ranking of 2.74 , these skills were generally 
perceived as not needed by entry-level employees but may be areas where training could be given at a later date so the employees harvesting timber have a better understanding of why foresters mark timber the way they do. With a better understanding of these concepts they may be motivated to perform their specific jobs better.

Starting salaries range form $\$ 4.00$ to $\$ 8.00$ per hour, with a mean hourly salary of $\$ 5.76$ per hour. Although this put the salary at or a little above minimum wage, it must be remembered that this study was concerned with entry-level positions, and it could not be expected to reflect salaries at the upper end of the pay scale for highly skilled and experienced woods-workers. Conclusion

Within the limitation of the study and based on the findings, the following conclusions were derived:

1. Owners/operators preferred to hire entry workers with a strong work ethic.

2. Owners/operators were willing to provide additional training to selected employees who desired to become certified loggers.

3. Owners/operators prefer to hire employees with basic harvesting skills.

4. Owners/operators noted that basic forestry skills were not as important as strong work ethic and harvesting skills.

5. Owners/operators were more likely to send more experienced employees to classes to become certified loggers. 


\section{Recommendations}

From the results of the investigation, the investigator proposes the following recommendations:

1. High school and technical school instructors need to strongly reinforce the importance of strong work ethics. Student should be expected to dress properly and work cordially with his/her fellow students. Instructors should consider operating their classes like a business; however, the students would not receive financial compensation but would earn a grade and a letter recommendation from the instructor.

2. High school and technical schools need to provide students with ample basic and advanced training in timber harvesting operations.

3. Program completers who are certified loggers stand a greater chance of employment.

4. Teachers of forestry programs need to establish internships with owners/operators in the industry.

5. Teachers of forestry programs need to establish contacts with local landowners, universities, state forest, state and local parks for use of lands to perform harvesting or salvage projects to give the students real world experience.

6. If more advanced training is required of entry-level employees in timber harvesting, than the employers must be willing to pay higher wages than were reported in this study.

7. Teachers of forestry programs need to establish contacts with local equipment dealers to give students experience with maintenance and operation of various types of timber harvesting equipment. 


\section{REFERENCES}

A list of occupations ranked in order of risk. (1989, January 8). Parade Magazine, p.4.

American Psychological Association. (2002). Publication Manual of the American Psychological Association (5 ${ }^{\text {th }}$ ed.). Washington, D. C.: American Psychological Association.

Ary, D., Jacobs L. C., \& Razavieh, A. (1990). Introduction to Research in Education. Orlando, FL: Harcourt Brace.

Dillman, D. A. (1978). Mail and telephone surveys. New York: John Wiley and Sons.

Logger Safety Checklist Booklet, (9/93 version). North Carolina Forestry Association, Inc.

The Vermont Logging Safety Handbook, (1992). University of Vermont, Extension service.

Tipton III, G. M. (1992). Perceptions and Values of Secondary Education as Expressed by Professional Foresters. (Doctoral dissertation), Iowa State University, Ames Iowa. 
APPENDICES 
APPENDIX - A

Questionnaire 


\section{Owner/Operators in the}

\section{Timber Harvesting Industry}

How many do you employ?

How many employees are certified loggers?

How many employees are involved in harvesting operation?

How many employees are involved in transportation operation?

How many employees are involved in equipment maintenance?

Approximately how many employees do you hire each year, in each area?

$\begin{array}{lll}\text { Felling } & \text { Transportation } \\ \text { Skidding } & \text { Maintenance }\end{array}$

Would you be willing to hire an entry level worker who has been trained at a vocational school and who possess minimal experience? Yes No

What would be the normal starting salary you would willing to pay a person with this type of training? \$ per hour.

Please circle the number in the rating scale given below, which most closely indicate importance of knowledge or skills needed by entry level employees:

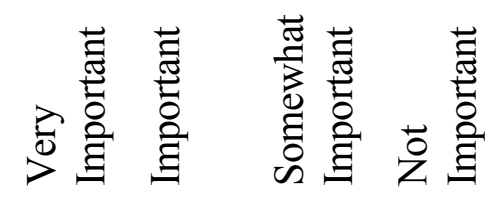

Training/Skills needed by entry level employees:

standard first aid

basic chain saw safety/operation

best management practices (BMP)

advanced chain saw training

silviculture

log grading

road layout

$\begin{array}{llll}1 & 2 & 3 & 4 \\ 1 & 2 & 3 & 4 \\ 1 & 2 & 3 & 4 \\ 1 & 2 & 3 & 4 \\ 1 & 2 & 3 & 4 \\ 1 & 2 & 3 & 4 \\ 1 & 2 & 3 & 4\end{array}$


road construction (dozer)

skidder safety/operation

dozer safety/operation

feller/buncher

$\log$ loader/log bucking saw

basic equipment maintenance

commercial drivers license

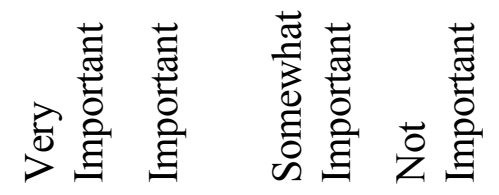

$\begin{array}{llll}1 & 2 & 3 & 4 \\ 1 & 2 & 3 & 4 \\ 1 & 2 & 3 & 4 \\ 1 & 2 & 3 & 4 \\ 1 & 2 & 3 & 4 \\ 1 & 2 & 3 & 4 \\ 1 & 2 & 3 & 4\end{array}$

Basic Skills:

business math

reading

writing

oral communication

Employer Expectations:

Attendance and punctuality

Cooperation with fellow workers

Can work with minimal supervision

$\begin{array}{llll}1 & 2 & 3 & 4 \\ 1 & 2 & 3 & 4 \\ 1 & 2 & 3 & 4 \\ 1 & 2 & 3 & 4\end{array}$

$\begin{array}{llll}1 & 2 & 3 & 4 \\ 1 & 2 & 3 & 4 \\ 1 & 2 & 3 & 4\end{array}$

Your Age (in years)?

Years of Experience in the Industry?

Are you a Certified logger? Yes No

Please check which county you live in?

Monongalia Marion Taylor Preston

Thank you for your cooperation. Please insert your questionnaire into the self addressed stamped enveloped provided for your convenience. 
APPENDIX - B

Initial Cover Letter 
May 4, 1995

Dear

We are conducting a thesis study of owners/operators in the timber harvesting industry to determine if there is a need to develop a forestry program in the county vocational schools. We need your assistance in gathering this important information.

Although your response is voluntary, we hope you will take a few minutes from your busy schedule to complete the enclosed survey. If there are statements you cannot or would rather not answer, feel free to leave them blank. Be assured that your response will be kept completely confidential.

I possible please return the completed survey by June 1, 1995. A self-addressed, postage paid envelope has been enclosed for your convenience. Thank you for your professional assistance.

Sincerely

Robert E. Driscole Forest Manager

West Virginia University

Stacy A. Gartin, Professor Agricultural Education 
APPENDIX - C

Second Cover Letter 
July 6, 1995

Dear

On May 4, 1995 you where sent a survey to determine if there is a need to develop a forestry program (timber harvesting) in the county vocational schools. The information provided by you is very important to the success of this project. Please take a few minutes out of your busy schedule, if you have not already done so, to complete the enclosed questionnaire. Be assured that your response will be kept completely confidential. A self-addressed, postage paid envelope has been enclosed for your convenience. Thanks you for your professional assistance.

Sincerely

Robert E. Driscole

Forest Manager

West Virginia University

Stacy A. Gartin, Professor Agricultural Education 
VITA 


\section{VITA}

NAME:

Robert Eugene Driscole

BIRTH DATE:

May 29, 1951

PLACE OF BIRTH:

Scranton, Pennsylvania

EDUCATION:

1970 High School: Neshaminy High School Langhorne, PA

1979 College: The Pennsylvania State University - B.S. Forestry.

2004 West Virginia University - Masters of Science Degree

Other: Lumber grading short course

\section{REGISTRATION:}

West Virginia State Board of Registration for Foresters - R.P.F.\# 217

Society of American Foresters, Certified Forester, \# 2088

West Virginia Certified Logger, \# 00571

PROFESSIONAL

SOCIETIES:

West Virginia Forestry Association

Member of Board of Directors 1990 to 1993

WVFA Safety Committee - member 1990 to present;

review and submit safety alerts for distribution to general membership.

Society of American Foresters 1981 to present

Secretary/Treasurer, Rothrock Chapter SAF - 1981 to 1983

Executive Committee, Rothrock Chapter SAF - 1979 to 1981

Member 


\section{EMPLOYMENT: 1983 to Present:}

Forest Manager of West Virginia University's Research Forest located outside Morgantown, West Virginia.

1979 to 1983: Resident Forester for The Pennsylvania State University's Stone Valley Experimental Forest located in Huntingdon, Pennsylvania.

1977 to 1979: Miscellaneous forestry related jobs while a student at The Pennsylvania State University.

\section{WORK}

\section{EXPERIENCE:}

Management and operation of the West Virginia University Research Forest, Tygart Valley Forest, and the Farm Woodlot and the Davies Tract (8,429 acres)- to obtain the teaching, research, and demonstration objectives for the forest as set by the Division of Forestry. Management of the Westvaco Natural Resources Center, Prepare timber sales and sale contracts, oversee harvesting operations and compliance of timber contracts by operators. Perform silvicultural operations - thinning and stand improvement, timber harvesting, conduct forest inventories, forest protection (fire), road location, construction and maintenance, sales of forest products (saw logs, pulpwood, and posts, fence rails, lumber, firewood, etc.). Submit annual plans of work, budgets, manage finances, purchase equipment, and supplies used in operation of the forest properties. Coordinate field activities to assist in teaching and research activities including recommend locations for projects, cut and transport logs for research, assist with summer camp, speak to classes, instruct graduate students in safety procedures. Maintain and secure all buildings. Operate, maintain, and repair, and secure equipment and vehicles.

Also responsible for overseeing the operation of the University Sawmill. 
COMMITTEE

WORK (WVU):
Forest Planning and Coordinating Committee - member

Forest Safety Committee - Chairman

Forest Roads Committee - Chairman
ACADEMIC EXPERIENCE:
Instructor of short course to Vocational/Agricultural teachers in proper timber felling techniques and chain saw safety at West Virginia University.

Instructor of short course to Agricultural/Forestry teachers from Chile, on the operation, maintenance, and safety of Forestry equipment.

Assisted with Division of Forestry summer camp - surveying, safety training, road layout and construction at West Virginia University.

Assist with log grading classes during summer camp and short course for local sawmill personnel at West Virginia University.

Consulted on video series entitled "Woodlot Management" with the Cooperative Extension at West Virginia University.

Instructor of proper felling techniques and chain saw safety to farm groups, individuals, and USFS personnel since 1983 at West Virginia University.

Instructor in standard First Aid for the American Red Cross - 1990 to 1994.

Public Service Announcements for the West Virginia University Extension Service on importance of Personal Safety Equipment when using a chainsaw.

Instructor in timber harvesting at Rockview State Correctional Institution in cooperation with the Continuing Education Program at The Pennsylvania State University - 1981 to 1982.

Assisted with teaching undergraduate course in pulp and timber harvesting at The Pennsylvania State University for four years. 
Consulting Forester:

- West Virginia State Forest Stewardship Program

- Timber sale administration

- Timber appraisal

- Expert Witness- Experience in appearing as an expert witness in magistrate court, insurance company, and Attorneys at Law in West Virginia and Pennsylvania. Investigations have dealt with timber trespass, accidental death (timber felling), accident associated with overloaded log truck, gas well reclamation.

HONORS:

1991 Division of Forestry year book "The Cruiser" dedication.

Member of Honor Society of Agriculture - Gamma Sigma Delta - 1986

Outstanding member of The Pennsylvania State University Forestry Society - 1978

\section{COMMUNITY:}

Explorer Post Advisor, BSA - Post 2200 Marksmanship 1996- present

Boy Scouts of America Troop 49 Committee Chairman 1992 - 1997, committee member.

Conservation Committee Chairman for Camp Mountaineer - 1990 -1993, committee member 1993 - 1998.

Webelos leader, Pack 77

Camp Committee for camp Mountaineer 1994- 1998.

Woodburn Elementary School - PTA 1987-1990 
National Rifle Association - Life member

Mason-Dixon Rifle Club - Secretary, Board of Directors, High power match director, Smallbore match director, Junior Coach and Pistol instructor.

\section{PUBLICATION/ PRESENTATIONS:}

"A modular Timber Bridge for Temporary Stream Crossings," proceedings of Council Forest Engineering Annual Meeting, Outer Bank, N.C., August 12-16, 1990

\section{REFERENCES:}

Joe McNeel, Director

Division of Forestry

Davis College of Agriculture, Forestry

and Consumer Sciences

West Virginia University

Morgantown, WV 26506

304-293-2941

Harry V. Wiant, Jr.

113 Scenery Dr.

Morgantown, WV 26506

304-599-6618 